\title{
Flexible Exchange Rate, Financial Development and Economic Performance in Malaysia: An Econometric Analysis
}

Ram N. Agarwal*

OYA Graduate School of Business, University Uttara Malaysia, Malaysia

\begin{abstract}
In this paper evidence on whether Malaysia's, Bank Negara policy of allowing flexible exchange rate along with financial development has affected the volatility of real macroeconomic variables like trade, foreign investment and economic growth is presented. An econometric framework is also utilized to examine the linkages between the exchange rate and the real economy. Different indicators of financial development and exchange rate variability are used. Results are found to vary with the indicators used. Correlation matrix shows that Variability in real effective exchange rate has an adverse effect on the inflow of FDI and economic growth. While the development of Capital market has a positive correlation with FDI, trade and economic growth. Credit to the private sector by the financial institutions has a positive impact on the international trade intensity. Regression results show that variability in exchange rate has a significant negative impact on economic growth. While its effect on trade intensity is not conclusive.
\end{abstract}

Keywords: Real effective exchange rate; Variability in exchange rate; Measures of variability of exchange rate; Economic growth; International trade; Financial Development Indicators (FDI); JEL Classification: F31, F10

\section{Introduction}

According to a United Nation's publication" “ world Economic Situation and Prospects 2012 "exchange rates among major international reserve currencies, namely, the United States dollar, euro and Japanese yen, has continued to display large fluctuations during 2011 and developing countries also witnessed greater exchange-rate volatility. The dollar has continued its downward trend against other major currencies in the first half of the year, but rebounded notably against the euro in the third quarter when concerns about the sovereign debt crisis in the euro area intensified, and devalued again later in the year after some agreements were reached in Europe on scaling up measures to deal with the debt crisis. Over the year as a whole, the Japanese yen has appreciated against both the dollar and the euro, despite interventions by the Bank of Japan to curb the appreciation. Among other currencies in developed economies, the Swiss franc has appreciated the most in the first half of the year, as a result of flightto-safety effects, leading to the decision of the Swiss authorities not to tolerate any strengthening of the exchange rate below SwF 1.20 per euro. Strong capital inflows attracted by robust economic performance put upward pressure on the currencies of most emerging economies over the past two years. This trend went into a tailspin with the heightened turbulence in global financial markets starting in mid2011. For instance, Brazil's real effective exchange rate fell 16 percent against the United States. Dollar in the third quarter, while the Russian rouble and the South African rand depreciated by 15 and 19 percent, respectively.

The increased currency volatility has injected an additional element of uncertainty into currency markets and created significant feed-through effects into the real economy. As companies face greater difficulties in pricing their products and anticipating their costs, business planning becomes more uncertain, underpinning a generally more cautious approach that also includes an even greater reluctance to hire new employees. Such increased volatility would also be likely

${ }^{1}$ United Nation publication 2012 - World Economic Situation and Prospects 2012. ${ }^{2}$ Bretton Woods II model of the World Economy1973. to spill over into more price instability in commodity markets given the high degree of financialization of those markets and the impact of exchange rates (especially the value of the dollar) on commodity prices. Uncertainty and volatility in currency markets can be expected to remain high during 2012-2013.

The earlier experience of Asian crisis has focused attention on the real costs that fixed exchange rates can lead to when a country is forced to realign or float a misaligned exchange rate. The flexible exchange rates have costs of their own. Nominal and real exchange rate volatility under flexible exchange rates is much larger than volatility in fundamentals. Such volatility may translate into reduced trade and economic growth. Using the real exchange rate to provide an incentive to shift resources into manufacturing provides a boost to national income insofar as there are conditions making for higher productivity in manufacturing than in agriculture. The literature on export-led growth is essentially about the advantages of keeping the prices of exportable high enough to make it attractive to shift resources into their production. That first Japan, then Hong Kong, Singapore, South Korea and Taiwan, and now China have had success with this model has directed attention to the real exchange rate as a development-relevant policy tool. The so called Bretton Woods II model of the world economy is essentially a story about The Real Exchange Rate and Economic Growth by developing countries ${ }^{2}$. The current focus is not only on the level of the real exchange rate but on its volatility also. The modern experience is that exchange rate volatility discourages trade and investment, which are important for growth. The literature on financial fragility shows that sudden drops in the exchange rate can have disruptive financial consequences. In particular, currency crises (essentially episodes when there is a sharp increase in exchange rate volatility, which are measured

${ }^{*}$ Corresponding author: Ram N. Agarwal, Visiting Professor of Economics, OYAGraduate School of Business, University Uttara Malaysia, Malasiya, Tel: +6049285207, +6013-5257536; E-mail: ram_ieg@yahoo.co.in

Received February 15, 2012; Accepted May 08, 2012; Published May 10, 2012

Citation: Agarwal RN (2012) Flexible Exchange Rate, Financial Development and Economic Performance in Malaysia: An Econometric Analysis. J Bus Fin Aff 1:103. doi:10.4172/2167-0234.1000103

Copyright: (c) 2012 Agarwal RN. This is an open-access article distributed under the terms of the Creative Commons Attribution License, which permits unrestricted use, distribution, and reproduction in any medium, provided the original author and source are credited. 
in practice as a weighted average of exchange rate changes and reserves changes, with stress on the former) can have significant costs in terms of growth foregone. However, the relationship between exchange rate volatility and growth is disputed. The evidence linking exchange rate volatility to exports and investment is less than definitive. The implications of volatility for financial stability and growth will depend on the presence or absence of the relevant hedging markets-and on the depth and development of the financial sector generally. There is some evidence that these markets develop faster when the currency is allowed to fluctuate and that banks and firms are more likely to take precautions, hedging themselves against volatility, than when the authorities seek to minimize volatility. Similarly, there exists evidence that the real exchange rate matters, keeping it at competitive levels and avoiding excessive volatility are important for growth. However, the statistical evidence is not overwhelming.

\section{Objective of the Study}

In view of the complexity of the effect of exchange rate risk, this study is motivated to examine the relationship among exchange rate volatility, trade intensity and economic growth in a multivariate setting. The paper will proceed as follows.

In the following section, evidence on the volatilities of a number of macroeconomic variables relevant to Malaysia's economic performance is presented. The theory of linkages between exchange rate variability and the macroeconomic performance along with the role of financial development is explained in "Real exchange rate, trade and economic growth: theory". Review of literature is briefly outlined in "Flexible exchange rate and the macroeconomy: review of literature". The econometric formulation linking together the two major indicators of economic performance and volatility in exchange rate is presented in "The model" and the final section provides empirical findings and policy implications.

\section{Volatilities in Macroeconomic Variables in Malaysia}

Pre-crisis, Malaysia had a large current account deficit of $5 \%$ of GDP. At the time, Malaysia was a top investment destination, and this was reflected in KLSE activity which was regularly the most active exchange in the world. (with turnover exceeding even markets with far higher capitalization like the NYSE). Expectations at the time were that the growth rate would continue, propelling Malaysia into developed status by 2020, a government policy articulated in Wawasan 2020. As at start of 1997, the KLSE Composite index was above 1,200, the ringgit was trading above 2.50 to the dollar, and the overnight rate was below $7 \%$.

In July, within days of the Thai baht devaluation, the Malaysian ringgit was "attacked" by speculators. The overnight rate jumped from under $8 \%$ to over $40 \%$. This led to rating downgrades and a general sell off on the stock and currency markets. By end 1997, ratings had fallen many notches from investment grade to junk, the KLSE had lost more than $50 \%$ from above 1,200 to under 600 , and the ringgit had lost $50 \%$ of its value, falling from above 2.50 to under 3.80 to the dollar.

In 1998, the output of the real economy declined plunging the country into its first recession for many years. The construction sector contracted $23.5 \%$ manufacturing shrunk $9 \%$ and the agriculture sector $5.9 \%$ Overall, the country's gross domestic product plunged $6.2 \%$ in 1998. During the year, the ringgit plunged below 4.7 and the KLSE fell

${ }^{3}$ Crawling peg regime is the regime in which currency is pegged, but can be changed if required. below 270. In September that year, various defensive measures were announced to overcome the crisis.

The principal measures taken were to move the ringgit from a free float to a fixed exchange rate regime. Bank Negara fixed the ringgit at 3.8 to the dollar. Capital controls were imposed. Various agencies were formed. The CDRC (Corporate Debt Restructuring Committee) dealt with corporate loans. Dana harta discounted and bought bad loans from banks to facilitate orderly asset realization. Dana modal recapitalized banks. Growth then settled at a slower but more sustainable pace. The massive current account deficit became a fairly substantial surplus. Banks were better capitalized and NPLs were realized in an orderly way. Small banks were bought out by strong ones. A large number of PLCs were unable to regularize their financial affairs and were de listed. Asset values however, have not returned to their pre crisis highs. In 2005 the last of the crisis measures was removed as the ringgit was taken off the fixed exchange system.

Malaysian economy generally prefer to follow more flexible exchange rate regime after the collapsed of Bretton Wood system. However, in spite of the adoption of a crawling peg exchange rate regime $^{3}$ in the period after the breakdown of the Bretton Woods system. After the Asian crisis, the Malaysia ringgit was pegged to the US dollar. Outliers observed after the crisis indicate pegging adjustments made by Bank Negara, Malaysia’s central bank.

Given its importance in promoting regional prosperity, the issue of how we could reduce the extent of exchange rate volatility and misalignment should be put in the first place. The recent regional financial crisis has renewed calls for greater monetary integration and regional exchange rate stability in South-East Asia (SEA). One of the proposals raised during the 1998 by the former Philippines' President Estrada at the ASEAN Ministerial Meeting in Hanoi was the idea of having a common currency and exchange rate system in the region. In the November 1999 meeting of the ASEAN, further emphasis had been given on this issue and urged the 10 ASEAN members to work harder to achieve their target of having a common market, single currency and one community [1]. Over the long run, as South-East Asia move towards realization of a monetary union, the resulting stability in exchange rate environment could pave the way for better growth prospects and prosperity in South-East Asia. In short, exchange rate misalignment is currently a critical challenge to Malaysia economy. High exchange rate volatility will be an unfavorable phenomenon to the country because it can aggravate the problem of external debt, reduce the domestic investment resources and ultimately distort the country's economic growth and development.

\section{Real Exchange Rate, Trade and Economic Growth : Theory}

The theory suggests that real exchange rate and its stability both matter for growth. If the exchange rate becomes significantly overvalued / undervalued, it will affect exports and imports. Then the right approach to fostering growth and development is to realign it. But what exactly is the mechanism through which a competitive real exchange rate fosters growth? Avoiding real overvaluation may simply encourage the optimally balanced growth of traded- and nontradedgoods producing sectors. Alternatively, there may be non-pecuniary externalities associated with the production of exportables (learning by doing effects external to the firm) that do not exist to the same degree in other activities-meaning that market forces, left to their own devices, may produce a real exchange rate that is too high. There is now substantial literature linking the level of the real exchange rate 
to output growth. Hausmann et al. [2] examine episodes when growth accelerates by at least two percentage points and that acceleration lasts for at least eight years. Considering 80 some episodes, they find that real depreciation is among the factors that are significantly associated with their incidence. Aghion et al. [3] find that countries suffering from real overvaluation experience slower productivity growth. This effect shrinks in magnitude, as noted above, as countries become financially more developed. All this takes the real exchange rate as exogenous.

\section{Exchange rate volatility, trade and economic growth}

How (real) exchange rate volatility can affect the level of the firm's exports is well explained by Clark [4]. He considers a competitive firm with no market power producing only one commodity which is sold entirely to one foreign market and does not import any intermediate inputs. The firm is paid in foreign currency and converts the proceeds of its exports at the current exchange rate, which varies in an unpredictable fashion, as there are assumed to be no hedging possibilities, such as through forward sales of the foreign currency export sales. Moreover, because of costs in adjusting the scale of production, the firm makes its production decision in advance of the realization of the exchange rate and therefore cannot alter its output in response to favorable or unfavorable shifts in the profitability of its exports arising from movements in the exchange rate. In this situation the variability in the firm profits arises solely from the exchange rate, and where the managers of the firm are adversely affected by risk, greater volatility in the exchange rate - with no change in its average level leads to a reduction in output, and hence in exports, in order to reduce the exposure to risk. This basic model has been elaborated by a number of authors, e.g., Hooper and Kohlhagen [5], who reach the same conclusion of a clear negative relationship between exchange rate volatility and the level of trade. However, this strong conclusion rests on a number of simplifying assumptions. First, it is assumed that there are no hedging possibilities either through the forward exchange market or through offsetting transactions. For advanced economies where there are well developed forward markets, specific transactions can be easily hedged, thus reducing exposure to unforeseen movements in exchange rates. But it needs to be recognized that such markets do not exist for the currencies of most developing countries. Moreover, even in advanced economies the decision to continue to export or import would appear to reflect a series of transactions over time where both the amount of foreign currency receipts and payments, as well are the forward rate, are not known with certainty. Moreover, there are numerous possibilities for reducing exposure to the risk of adverse exchange rate fluctuations other than forward currency markets. The key point is that for a multinational firm engaged in a wide variety of trade and financial transactions across a large number of countries, there are manifold opportunities to exploit offsetting movements in currencies and other variables. In a similar vein, as noted by Clark [4], to the extent that an exporter imports intermediate inputs from a country whose currency is depreciating, there will be some offset to declining export revenue in the form of lower input costs. In addition, when a firm trades with a large number of countries, the tendency for some exchange rates to move in offsetting directions will provide a degree of protection to its overall exposure to currency risk. One reason why trade may be adversely affected by exchange rate volatility stems from the assumption that the firm cannot alter factor inputs in order to adjust optimally to take account of movements in exchange rates. When this assumption is relaxed and firms can adjust one or more factors of production in response to movements in exchange rates, increased variability can in fact create profit opportunities.
This situation has been analyzed by De Grauwe [6]. The effect of such volatility depends on the interaction of two forces at work. On the one hand, if the firm can adjust inputs to both high and low prices, its expected or average profits will be larger with greater exchange rate variability, as it will sell more when the price is high, and vice versa. On the other hand, to the extent that there is risk aversion, the higher variance of profits has an adverse effect on the firm and constitutes a disincentive to produce and to export. If risk aversion is relatively low, the positive effect of greater price variability on expected profits outweighs the negative impact of the higher variability of profits, and the firm will raise the average capital stock and the level of output and exports. One aspect of the relationship between trade and exchange rate volatility that needs to be mentioned is the role of "sunk costs." Much of international trade consists of differentiated manufactured goods that typically require significant investment by firms to adapt their products to foreign markets, to set up marketing and distribution networks, and to set up production facilities specifically designed for export markets. These sunk costs would tend to make firms less responsive to short-run movements in the exchange rate, as they would tend to adopt a "wait and see" approach and stay in the export market as long as they can recover their variable costs and wait for a turnaround in the exchange rate to recoup their sunk costs.

\section{Financial development and economic growth: theory}

In this section, we review the main theoretical rationales for a positive effect of financial development on economic growth and provide a brief overview of the large and growing empirical literature that investigates the financial development-growth nexus.

A financial system consists of financial institutions-e.g., commercial banks-and financial markets-e.g., stock and bond markets. At a broader level, a robust and efficient financial system promotes growth by channeling resources to their most productive uses and fostering a more efficient allocation of resources. A stronger and better financial system can also lift growth by boosting the aggregate savings rate and investment rate, speeding up the accumulation of physical capital. Financial development also promotes growth by strengthening competition and stimulating innovative activities that foster dynamic efficiency. According to Demirgüç-Kunt et al. [7], the overall function of a financial system is to reduce information and transactions costs impeding economic activity, and its five core functions are to (i) produce ex ante information about possible investments and allocate capital; (ii) monitor investments and provide corporate governance after providing finance; (iii) facilitate the trading, diversification and management of risk; (iv) mobilize and pool savings; and (v) ease the exchange of goods and services. The efficiency of a financial system refers to how well a financial system performs the five core functions and financial development refers to an improvement in the efficiency of a financial system. These five core functions provide a clearer understanding of the nexus between financial development and economic growth.

First and foremost, financial systems produce information and allocate capital. The textbook world of scarce capital seamlessly flowing to the most productive firms and industries is a world that assumes away information costs. The intermediation of savings into investments depends on the quality and quantity of information available to individual savers, but it may be too costly individual savers to acquire information on their own. Financial intermediaries such as banks collect, process, and produce information on possible investments more efficiently than individual savers. Armed with more and better 
information, financial intermediaries will invest in more promising firms and industries. Large and liquid stock markets also encourage the acquisition of information by making firm-specific information more profitable.

Then, financial systems monitor firm behavior and exert corporate governance. By improving corporate governance, financial intermediaries can have a positive effect on growth. Stock markets can also serve as a powerful for aligning the interests of firm mangers with those of firm owners.

Third, financial instruments, intermediaries, and markets can facilitate the trading, hedging, and pooling of risk. By enabling risk diversification across firms and industries, financial systems can influence the allocation of resources and hence economic growth.

Fourth, Financial systems that are better able to mobilize savings create a larger pool of savings that lead to higher aggregate investment, faster rate of capital accumulation, and hence faster economic growth.

Fifth, at a more fundamental level, financial instruments, intermediaries, and markets can stimulate specialization, innovation, and growth by reducing transactions costs. The transition from barter economy to a monetary economy brings about a quantum leap in efficiency and welfare as a result of the three basic functions of money-means of payment, unit of account, and store. By reducing the transactions costs of economic exchange and activity, money enables workers to specialize in specific activities. Greater specialization, in turn, improves the capacity of workers to create new technologies and products. The end result of increased specialization and innovation is faster economic growth.

\section{Financial development and growth: evidence}

A large and growing empirical literature has sprung up to examine the relationship between finance and growth. At a broader level, the literature looks at the impact on Gross Domestic Product (GDP) growth of the depth of the financial system, as measured by indicators such as the ratio of total liquid liabilities to GDP, the ratio of bank credit to GDP, or the ratio of stock market capitalization to GDP. The evidence from the empirical literature strongly indicates that financial depth has a significant positive effect on growth. More specifically, bank development and stock market development exerts a significant positive effect on growth, as does overall financial development. Although a shift from banks to capital markets is often viewed as evidence of financial development, countries with market-based financial systems do not perform better than those with bank-based systems. Therefore, the broader finding from the empirical literature is that what matters for economic performance is overall financial development rather than the relative weight of its various components.

In a comprehensive review of the empirical literature, DemirgüçKunt et al. [7] point out that the literature contains four different types of studies: (i) pure cross-country growth regressions, (ii) panel techniques that make use of both the cross-country and time-series dimensions of the data, (iii) microeconomic studies that explore the various channels through which finance may affect economic growth, and (iv) individual country case studies.

The first approach involves the application of broad cross-country growth regressions, which seek to explain growth through standard explanatory variables such as physical and human capital, to the study of finance and growth. These studies typically aggregate growth over long periods of time and examine the relationship between long-run growth and various measures of financial development. The second approach involves the analysis of panel data and seeks to mitigate some of the econometric problems associated with the pure crosscountry approach. The second approach has a number of well-known advantages vis-à-vis the first approach even though it also suffers from some disadvantages. The third approach uses firm-level and industrylevel data to assess the impact of financial development on firm and industry performance. A positive impact would lend support to the notion that financial development is beneficial for growth. The fourth country drops the cross-country dimension and looks at the finance growth in a single individual country. For example, some studies analyze the impact of a specific policy change in a country.

Empirical assessment of the relationship between growth and financial development involves a wide range of econometric techniques and data sets. In the earlier cross-country regression studies, economic growth is usually averaged over long periods while financial indicators are either averaged over the same period or taken from the initial year. In addition, a number of macroeconomic indicators are used as control variables. A pioneering early study in King and Levine [8], who examined the relationship between financial depth, as measured by liquid liabilities, and three growth measures, namely, real per capita GDP growth, real per capita capital stock growth, and total productivity growth, all averaged over the sample period. Using data for 77 countries over the period 1960-1989, they find a statistically significant positive relationship between financial depth and the three growth measures. The study by Levine and Zervos [9] find the initial level of banking development and stock market activity as having statistically significant relationships with average output growth, capital stock growth, and productivity growth, based on data for 47 countries over the period 1976-1993. They use bank credit to the private sector as measure of banking development. For stock market development, they use turnover ratio and value traded to represent stock market liquidity, and stock market capitalization to measure size of the equity market. Stock market liquidity measures are found to be robust predictors of future economic growth but stock market size is not. In addition, the results of stock market size regression are strongly influenced by a few countries.

Beck et al. [10] apply panel econometric techniques along with new data to re-examine the relationship between stock markets, banks, and economic growth. They examine whether measures of stock market and bank development each have a positive relationship with economic growth after controlling for simultaneity bias and omitted variable bias. They use data for 40 countries, averaged over 5 years from 1976 to 1998, and employ Generalized Method of Moments (GMM) estimators for panel data analysis. Both stock markets and banks are found to be jointly significant in affecting economic growth in their panel estimation, thus suggesting that stock markets provide different financial services from banks.

The study by Levine, Sara and Beck et al. $[9,10]$ likewise implement GMM panel estimators to analyze the link between financial development and growth. In addition, they complement this with a cross-country instrumental variable regression. For the panel estimation, data are averaged over each of the seven 5-year intervals over the period 1960-1995 for 74 countries. They conclude that the significant link between financial intermediary development and economic growth is not due to potential biases induced by omitted variables, simultaneity, or reverse causation. Regardless of the econometric techniques and data set employed, a growing body of evidence indicates that financial development is important for growth. 


\section{Flexible Exchange Rate and the Macroeconomy: Review of Literature}

According to Moosa and Imad [11], international trade is habitually affected by the exchange rate variability, which is known as exchange rate misalignment and volatility. Exchange rate misalignment can be defined as the deviation of the real exchange rate from its long run equilibrium path, which can distort comparative advantages, that is, the basis of the Ricardian international trade; while exchange rate volatility is commonly referred as a short-term exchange rate fluctuation measured by the conditional variance of the exchange rate, which believed may inhibits the growth of trade. Exchange rate risk might decrease export demand due to an uncertainty for future profit [12-14]. Among others, Bredin et al. [15] and De Vita and Abbott [16] found significant relationship between exchange rate volatility and export in the long run rather than in the short run. In the aspect of foreign investment, Crowley and Lee [17] found a weak relationship between exchange rate volatility and foreign direct investment if the movement of exchange rate was stable but a strong relationship when the movement of exchange rate was volatile. However, Darby et al. [18] found both situations where exchange rate uncertainty could either decrease or have no impact on the investment. For the exchange rate volatility and economic growth, Grier and HernándezTrillo [19] observed an appreciation of exchange rate was positively related to economic growth and an increased in exchange rate volatility was negatively related to economic growth. In recent, Agbeyagbe and Osakwe [20] believed that exchange rate volatility would have an impact on real economy, however, their results were inconclusive after examining flexible, fixed as well as a collapsing fixed-rate regime pertaining to South Korea's economy. Movements of exchange rate are always the concern for various parties. The outbreak of the Asian financial crisis 1997-98, starting with the sharp devaluation of Thai baht, had brought about a severe depreciation of regional currencies over a short period of time. Inevitably, the impact of exchange rate volatility was great and the catastrophic effect of the Asian crisis-1997 had since forced many economies to liberalise their exchange rate policies. In line with the liberalisation and globalisation, international financial markets are increasingly integrated and capital mobility becomes greater. All these have led to a more complex intertwined set of financial systems and great instability found in exchange rate variability which in turn tends to give a certain impact on the economy. In this study, the impact of exchange rate volatility is, therefore, investigated to uncover the spill-over effect of exchange rate volatility to external sector, international capital movement and economic growth for the four economies-Malaysia, Indonesia, Thailand and Singapore. Even though these economies are adopting semi-rigid exchange rate arrangement, the nominal currencies of these nations might not produce fixed and predictable real exchange rates and its parity level might be deviated. Their currencies most likely will also vary despite of its pegging system, resulting from the implicit weight of the currency that one country pegs might fluctuate substantially. In 1984 the IMF [21] produced a study for the General Agreement on Tariffs and Trade (GATT) on the impact of exchange rate volatility on world trade. That study was motivated by an increase in protectionist pressures, large exchange rate movements among the major currencies, and a significant slowdown in world trade. Some of these developments have reappeared. For example, the growth in world exports of goods and services declined sharply in 2001 and 2002 from the double-digit pace in 2000, and the exchange value of the U.S. dollar has fluctuated fairly sharply in the last year.
The 1984 study also reflected a desire to take stock of the implications for currency volatility and trade of the shift from the largely fixed rates among the major currencies to floating after the breakdown of the Bretton Woods system in 1971-1973. As there have been other major developments in the international monetary system since then, it is appropriate to revisit the issues addressed in that study some 20 years later. Some of these developments would appear to have exacerbated fluctuations in exchange rates. The liberalization of capital flows in the last 30 years and the enormous increase in the scale and variety of cross-border financial transactions have clearly increased the magnitude of exchange rate movements in those countries with underdeveloped capital markets and where there is not yet a track record of consistently stable economic policies. Crises in emerging markets, which have become more frequent in the last two decades, are especially notable cases of large exchange rate volatility. This has been of particular concern to developing countries and emerging market economies. In addition, the transition to a market-based system in Central and Eastern Europe often involves major adjustments in the international value of these economies' currencies. Other changes in the world economy may have reduced the impact of exchange rate volatility. The proliferation of financial hedging instruments over the last 20 years could reduce firms' vulnerability to the risks arising from volatile currency movements. In addition, for multinational firms, fluctuations in different exchange rates may have offsetting effects on their profitability. As a growing fraction of international transactions is undertaken by these multinational firms, exchange rate volatility may have a declining impact on world trade. On balance, it is not clear whether the major changes in the world economy over the past two decades have operated to reduce or increase the extent to which international trade is adversely affected by fluctuations in exchange rates. One aspect of this issue is the extent to such volatility itself has changed, and another is the degree to which firms are sensitive to exchange rate risk and can take steps to mitigate it at low cost. It is therefore necessary to examine new empirical evidence at this issue. Calvo and Reinhart [21] have also dealt with the issue. According to them, many countries, In recent years, have suffered severe financial crises, producing a staggering toll on their economies, particularly in emerging markets. One view blames fixed exchange rates-- soft pegs'-for these meltdowns. Adherents to that view advise countries to allow their currency to float. They analyze the behavior of exchange rates, reserves, the monetary aggregates, interest rates, and commodity prices across 154 exchange rate arrangements to assess whether official labels' provide an adequate representation of actual country practice. They find that, countries that say they allow their exchange rate to float mostly do not--there seems to be an epidemic case of fear of floating.' Since countries that are classified as having a free or a managed float mostly resemble noncredible pegs-the so-called demise of fixed exchange rates' is a myth--the fear of floating is pervasive, even among some of the developed countries.

\section{The Model}

From the above discussion it can be concluded that the real exchange rate and its variability affect foreign trade, flow of foreign capital into the country (FDI) and economic growth. This effect may be reduced through financial developments in the host country. Thus the econometric model is specified as under:

Trade Intensity $=\mathrm{f}$ (Real exchange rate, Exchange rate variability, financial

Development, FDI intensity, Economic Growth) (i) 
Citation: Agarwal RN (2012) Flexible Exchange Rate, Financial Development and Economic Performance in Malaysia: An Econometric Analysis. J Bus Fin Aff 1:103. doi:10.4172/2167-0234.1000103

Economic Growth $=f($ Real exchange rate, Exchange rate variability,

financial development, Trade Intensity, FDI Intensity)

\section{Estimation of the model}

The model is estimated by the two stage least square method (2SLS) of estimation due to the existence of endogenous variables as economic growth and trade intensity after testing for the stationarity of the variables.

\section{Notations used}

Annual National Income $=$ GDP of GDP

Economic Growth $=$ Growth of National income $=$ Annual Growth

Trade Intensity $($ tradeint $)=$ Annual $($ Imports + Exports $) /$ GDP

Real Effective Exchange rate $=$ REER

Exchange Rate variability = VAR1 and VAR2 (Appendix-4)

Financial Development Indicators = FINDEV1, FINDEV2, FINDEV3 (Appendix -1)

Foreign Direct Investment in the Country $=$ FDI

FDI Intensity $=$ FDI / GDP

DtradeInt $=$ TradeIntt - TradeIntt -1

Annual change in the variable $=\mathrm{D}($ Variable $)$

\section{Empirical Findings and Policy Implications}

Augmented Dickey-Fuller [23] unit root test has been applied for knowing the degree of stationarity of the macroeconomic variables considered here. Results (given in the appendix -3) show that trade intensity (tradeint) variable is not stationary while its first difference (Dtradeint) becomes stationary. Similarly, test on FDI shows that the first difference of FDI intensity variable is stationary. GDP growth variable is found stationary.

Regression results based on 2-SLS method of estimation (Appendix -5) show that financial development indicators along with the variability in exchange rate have no significant impact on trade. Although the impact of exchange rate variability on trade is positive. This may be due to the biases induced by some of the omitted variables in the analysis like productivity growth, capital stock growth etc.

Variability in exchange rate is found to have a negative and statistically significant impact on GDP growth even in the presence of financial development indicators. But FDI shows a positive and significant effect on GDP growth.

\section{Policy implications}

Based on the above analysis we can conclude that variability in exchange rate has a significant negative effect on economic growth and not on foreign trade. Financial developments in the economy have not been sufficient to control the negative effect. Therefore it is suggested that the central bank should intervene at times to control abnormal fluctuations in the exchange rate and minimize its variability otherwise the economic growth in the country can be adversely affected.

\section{Acknowledgement}

This paper was prepared while the author was working at the University Uttara
Malaysia as a visiting Professor during October 2010 to march 2012. I express my sincere thanks to the referee of the papers for his valuable suggestions and comments for the paper.

\section{References}

1. Hurley DT, Santos RA (2001) Exchange rate volatility and the role of regional currency linkages: the ASEAN case. Applied Economics 33: 1991-1999.

2. Hausmann R, Pritchett L, Rodrik D (2005) Growth accelerations. Journal of Economic Growth 10: 303-329.

3. Aghion P, Bacchetta P, Ranciere R, Rogoff K (2006) Exchange rate volatility and productivity growth: The role of financial development. J Monet Econ 56 : 494-513.

4. Clark PB (1973) Uncertainty, Exchange Risk, and the Level of International Trade. Western Economic Journal 11: 302-313.

5. Hooper P, Kohlhagen SW (1978) The effect of exchange rate uncertainty on the prices and volume of international trade. J Int Econ 8: 483-511.

6. Grauwe P DE (1988) Exchange rate variability and the slowdown in growth of international trade. IMF Staff Papers 35: 63-84

7. Beck T, Demirguc-Kunt A, Laeven L, Levine R (2008) Finance, Firm Size and Growth. J Money Credit Bank 40: 1379-1405.

8. King RG, Levine R (1993) Finance and growth: Schumpeter might be right. Q J Econ 108: 717-737.

9. Levine R, Sara Z (1998) Stock markets, banks, and economic growth. Am Econ Rev 88: 537-558.

10. Beck T, Demirgüç-Kunt A, Levine R (2000) A New Database on financial development and structure. World Bank Econ Rev 14: 597-605.

11. Moosa IA (2000) Exchange rate forecasting, techniques and applications. Macmilan Business London.

12. Arize AC (1997) Foreign trade and exchange-rate risk in the G-7 countries: Cointegration and error-correction models. Review of Financial Economics 6 : 95-112.

13. Doroodian K (1999) Does exchange rate volatility deter international trade in developing countries? J Asian Econ 10: 465-474

14. Doğanlar M (2002) Estimating the impact of exchange rate volatility on exports: evidence from Asian countries. Appl Econ Lett 9: 859-863.

15. Bredin D, Fountas S, Murphy E (2003) An empirical analysis of short-run and long-run Irish export functions: does exchange rate volatility matter? International Review of Applied Economics 17: 193-208.

16. De Vita G, Abott A (2004) The Impact of Exchange Rate Volatility on UK Exports to EU Countries. Scott J Polit Econ 51: 62-81.

17. Crowley P, Lee J (2003) Exchange rate Volatility and Foreign Investment International evidence. The International Trade Journal 17: 227-252.

18. Darby J, Hallet AH, Ireland J, Piscitelli L (1999) The Impact of Exchange Rate Uncertainty on the Level of Investment. The Economic Journal 109: 55-67.

19. Grier KB, Hernández-Trillo $F$ (2004) The real exchange rate process and its real effects: the cases of Mexico and the USA. J Appl Econ 7: 1-25.

20. Terence DA, Patrick NO (2005) Real exchange rate volatility and the choice of regimes in emerging markets. J Asian Econ 15: 1005-1022.

21. International monetary Fund (1984) The Impact of Exchange Rate Volatility on world Trade. General Agreement on Trade and Tariff (GATT).

22. Guillermo CA, Reinhart CM (2000) Fear of Floating. Quarterly Journal of Economics 107: 379-408.

23. Dickey DA, Fuller WA (1979) Distribution of the estimators for autoregressive time series with a unit root. J Am Stat Assoc 74: 427-431. 